\title{
PERTANGGUNGJAWABAN PIDANA ANGGOTA POLISI LALU LINTAS YANG MELAKUKAN PENGANIAYAAN PADA SAAT BERTUGAS
}

\author{
Criminal Liability of Traffic Policemen Who Conduct Persecution While On Duty \\ Andi Sumange Alam, Marwan Mas ${ }^{2}$, Ruslan Renggong ${ }^{2}$ \\ ${ }^{1}$ Polrestabe Kota Makassar \\ ${ }^{2}$ Program Studi Ilmu Hukum Program Pascasarjana Universitas Bosowa \\ Email: andigalang87@gmail.com
}

Diterima: 10 Januari 2021/Disetujui: 01 Juni 2021

\begin{abstract}
ABSTRAK
Penganiayaan diartikan dengan sengaja menyebabkan perasaan tidak enak, rasa sakit, atau luka. Penganiayaan yang dilakukan anggota Polisi Lalu lintas atas dasar-dasar tertentu. Anggota Polri yang melakukan penganiayaan terhadap pengendara motor pada dasarnya tunduk pada Peradilan umum. Temuan yang diperoleh dari penelitian ini antara lain : (1) Penerapan hukum terhadap tindak pidana penganiayaan dengan pemberatan yang dilakukan oleh Anggota Polisi lalu lintas yang sedang ditangani oleh Propam Polrestabes Makassar yaitu melanggar Pasal 351 ayat 1 ke-3 dan 5 KUHP. (2) berdasarkan alat-alat bukti yakni keterangan saksi dan keterangan pelaku, pertanggungjawaban tindak pidana sebagai penegakan hukum, mencakup pengertian mengenai subjek dan objek dalam proses tegaknya hukum itu sendiri. Dalam penegakan hukum terhadap anggota Polri yang melakukan pelanggaran disiplin, Polri melalui Propam (Profesi dan Pengamanan) memiliki tanggungjawab dan tugas struktur organisasi di Polres. Hukuman Tindakan Disiplin, Kode Etik, dan Peradilan Umum merupakan bentuk pertanggungjawaban pidana. Penelitian ini dilaksanakan di Propam Polrestabes Makassar dengan melakukan wawancara langsung dan menganalisis proses hukum Tindak Pidana Penganiayaan yang di lakukan anggota Polisi Lalu lintas.
\end{abstract}

Kata Kunci: Polisi Lalu Lintas; Pertanggungjawaban Pidana; Penganiayaan.

\section{ABSTRACT}

Financial S Persecution is defined as causing unpleasant feelings, pain, or injury intentionally. Persecution committed by Traffic Policemen is based on certain principles. Indonesian policemen who abuse motorcyclists are basically subject to the general court. The findings obtained from this research include: (1) The implementation of the law against the persecution criminal act by aggravating the traffic policemen handled by Profession and Security (Propam) of Makassar Police is violating Article 351 verses 1 to 3 and 5 of the Criminal Code. (2) based on evidence from testimony of witnesses and statements of perpetrators, liability for criminal acts as law enforcement includes the notion of subjects and objects in the process of upholding the law itself. In enforcing the law against Indonesian Policemen who commit disciplinary violations, Indonesia National Police through Propam (Profession and Security) has the responsibility and task of the organizational structure at Police Stations. Disciplinary Action Punishment, Code of Ethics, and General Courts are forms of criminal liability. This research was conducted at Propam of Makassar Police Station by conducting direct interviews and deciding on the Criminal Act of Persecution by the Traffic Policemen.

Keywords: Traffic police; Criminal liability; Persecution

\section{PENDAHULUAN}

Indonesia merupakan negara hukum. Hal ini telah dinyatakan dengan tegas dalam penjelasan Undang-Undang Dasar Negara Republik Indonesia Tahun 1945 (UUD 1945) bahwa Negara Republik Indonesia berdasar atas hukum (rechstaat)", tidak berdasar atas kekuasaan belaka (machstaat). Sebagai suatu negara hukum Indonesia memiliki karakter yang cenderung untuk menilai tindakan-tindakan yang dilakukan oleh masyarakat atas dasar peraturanperaturan hukum.
Reformasi birokrasi Polri, dalam mewujudkan pemerintahan dan organisasi yang bersih (clean government and organitation), Polri terus melaksanakan program dan bertanggung jawab atas program reformasi dibidang penegakan hukum. Hal tersebut merupakan sebagai tindak lanjut, dikeluarkan Surat Keputusan Menteri Kehakiman No.28 Tahun 1998 tentang pembentukan Tim Reformasi Hukum, penegakan hukum merupakan ujung tombak dalam upaya memerangi suatu pelanggaran dan tindak pidana. (Pasal 13 Undang-undang No 2 Tahun 2002 Tentang Undang-undang Kepolisian RI).Tidak terkecuali Kepolisian 
yang merupakan alat negara yang diberikan kewenangan dalam menagkkan hukum. Upaya penegakan hukum yang dilakukan oleh pemerintah, tidak dapat dilepaskan dari kepolisian.

Sebagai aparat penegak hukum mereka harus memberi contoh yang baik, karena hal itu turut mempengaruhi kepatuhan masyarakat terhadap aturan hukum yang berlaku, Salah satu aparatur negara yang berada pada struktur penegakan hukum di Indonesia adalah Polisi Republik Indonesia (POLRI).

\section{METODE}

\section{a Lokasi Penelitian}

Untuk memperoleh data dan informasi yang diperlukan berkaitan dengan permasalahan dan pembahasan penulisan ini, maka penulis melakukan penelitian dengan memilih lokasi penelitian di Kota Makassar. Pengumpulan data dan informasi akan dilaksanakan diberbagai tempat yang dianggap mempunyai data yang sesuai dengan objek yang akan diteliti seperti di Polrestabes Makassar Dan Polda Sulsel.

\section{b Jenis dan Sumber Data}

Data yang diperoleh dalam penelitian ini dapat dikelompokkan dalam dua jenis, yaitu:

1. Data Primer.

Data Primer adalah data yang diperoleh langsung dari hasil wawancara secara langsung dalam pihak terkait.

2. Data sekunder.

Data sekunder adalah data yang diperoleh dari literatur, dokumen-dokumen serta peraturan perundang-undangan lainnya yang relevan dengan materi penulisan.

\section{c Teknik Pengumpulan Data}

Dalam penelitian ini digunakan beberapa teknik pengumpulan data yaitu:

1. Penelitian Pustaka (Library Research).

Penelitian Pustaka dilaksanakanuntuk mengumpulkan sejumlah data meliputi bahan pustaka yang bersumber dari buku-buku, telaah terhadap dokumen perkara serta peraturan-peraturan yang berhubungan dengan penelitian ini.

2. Penelitian Lapangan (Field Research).

Penelitian lapangan dilakukan dengan cara melakukan wawancara dengan pihak pihak yang dapat memberikan informasi yang berkaitan dengan judul yang ditulis untuk kelengkapan data yang akan dikumpulkan.

d Analisis Data

Data yang diperoleh atau data yang berhasil dikumpulkan selama proses penelitian dalam bentuk data primer maupun data sekunder dianalisis secara kualitatif kemudian disajikan secara deskriptif yaitu menjelaskan, menguraikan dan menggambarkan sesuai dengan permasalahan yang erat kaitannya dengan penelitian yang dilakukan oleh penulis.

\section{HASIL DAN PEMBAHASAN}

\subsection{Aturan Hukum Terhadap Tindak Pidana Yang Dilakukan Oleh Anggota Polisi Lalu Lintas Secara Turut Serta}

Warga masyarakat bukanlah kawula atau oknum yang karena kedudukan sosial dan/atau afiliasi kulturnya yang berbeda dari yang tengah berkuasa lalu boleh diperlakukan dengan sewenang-wenang. Warga adalah pengemban hak, sebagian malah diyakin bersifat kodrat dan asasi, oleh sebab itu tidak lagi boleh diperlakukan secara semena mena sebagai hamba-hamba oleh siapapun. Sementara hamba-hamba menurut Soetandyo Wignjosoebroto, (2002:487-488) "Mereka yang menanggung beban kewajiban, kewajiban asasi itu tak lain daripada kewajiban untuk menghormati dan untuk ikut menegakkan hak-hak sesama warga dan tidak sekali-kali terlahir dari kesewenangan sang penguasa. Bagaimanapun juga setiap warga negara itu harus dipandang berkedudukan sama di depan hukum. Oleh karena itu hukum merupakan suatu alat untuk mengatur keseimbangan berbagai hak dan kewajiban dalam pergaulan hidup di masyarakat, bersifat mengikat kepada setiap warganya." Penerapan dari asas Equality Before the Law dapat dilihat dalam kasus yang terjadi Kota Makassar, dimana beberapa anggota Kepolisian telah melakukan kekerasan terhadap seseorang yang mengakibatkan luka-luka yang kasusnya sebagai berikut:

\section{Posisi Kasus}

Awal kejadian terjadi pada bulan Juni 2019 atau setidaktidaknya pada suatu waktu dalam bulan Juni 2019 bertempat di jl.Gunung Bawakaraeng atau setidaknya pada suatu tempat yang masih termasuk daerah padat kendaraan bermotor, terdakwa Soeharto, SH Bin Beddu Matta dengan sengaja melakukan kekerasan, penganiayaan yang direncanakan terlebih dahulu tehadap saksi korban Faisal Saidiman.

2. Dugaan Penganiayaan

Dalam kasus tindak pidana penganiayaan oleh Polisi lalu Lintas ini di laporkan ke Propam Poltabes Makassar menurut Pasal 351 ayat (1) KUHP dengan unsur-unsur sebagai berikut:

a. Barang siapa.

b. Dengan sengaja melakukan penganiayaan

Menurut Penulis bahwa penerapan hukum pidana materil dalam kasus tindak pidana Penganiayaan yang dilakukan oleh terdakwa, Soeharto Bin Beddu Matta kurang tepat, karena apabila dilihat dari fakta-fakta dan keterangan saksi-saksi yang terungkap di kepolisian resort makassar sebagai mana yang telah dijelaskan di atas bahwa seharusnya dalam penerapan hukum pidana materiil terdakwa dituntut dengan Pasal 353 ayat (1) KUHP sebagaimana perbuatan tindak pidana penganiayaan yang dilakukan terdakwa merupakan perbuatan yang direncanakan lebih dulu sebagai mana yang diatur dalam Pasal 353 ayat (1) KUHP.

3.2. Belum terlaksananya Pertanggungjawaban Pidana terhadap Polisi Lalu lintas Yang Melakukan Penganiayaan terhadap Lalu lintas

Reformasi birokrasi Polri, dalam mewujudkan pemerintahan dan organisasi yang bersih (clean government and organitation), Polri terus melaksanakan program dan bertanggung jawab atas program reformasi dibidang penegakan hukum. Hal tersebut merupakan sebagai tindak lanjut, dikeluarkan Surat Keputusan Menteri Kehakiman No.28 Tahun 1998 tentang pembentukan Tim Reformasi Hukum, penegakan hukum merupakan ujung tombak dalam upaya memerangi suatu pelanggaran dan tindak pidana. (Pasal 13 Undang-undang No 2 Tahun 2002 Tentang Undangundang Kepolisian RI).Tidak terkecuali Kepolisian yang merupakan alat negara yang diberikan kewenangan dalam menagkkan hukum. Upaya penegakan hukum yang dilakukan oleh pemerintah, tidak dapat dilepaskan dari kepolisian.

Anggota Polri yang melakukan penganiayan terhadap pengendara motor pada dasarnya tunduk pada Peradilan umum. Dalam pertanggungjawaban pidana Polri tunduk pada Peradilan Umum, hal tersebut telah diatur dalam Undangundang No 2 Tahun 2002 Tentang Kepolisian Pasal 29 ayat 
(1) yang berbunyi: "Anggota Kepolisian Negara Republik Indonesia tunduk pada kekuasaan Peradilan Umum".

Penegakan hukum pada hakikatnya merupakan proses perwujudan ide-ide (ide keadilan, ide kepastian hukum, dan ide kemanfaatan sosial) yang bersifat abstrak menjadi kenyataan. Tiga unsur yang perlu diperhatikan dalam penegakan hukum yaitu Op. Cit. Sudikno Mertokusumo, Mengenal Hukum Suatu Pengantar, Yogyakarta: Liberty, 1999:

1. Kepastian hukum

2. Kemanfaatan

3. Keadilan

Tidak adanya penegakan hukum terhadap anggota Polri, membuat adanya tindak kekerasan yang dilakukan tidak memberikan efek jera kepada oknum anggota Polri. Banyaknya tindakan-tindakan yang mengotori hukum yang kemudian timbul ketidak percayaan masyarakat terhadap penegakan hukum di Negara ini.

3.3. Faktor-faktor Penyebab Belum Terlaksananya Pertanggungjawaban PidanaTerhadap Anggota Polisi Lalu lintas yang Melakukan Penganiayaan

a. Faktor Mentalitas Penegak hukum

Soerjono Soekanto, Teori Sosiologi tentang Pribadi dalam Masyarakat, (Jakarta: Ghalia Indonesia, 1998), Mental petugas dalam menegakkan hukum sering menjadi salah satu faktor yang mempengaruhi dalam penegakan hukum. Permasalahan yang timbul dari faktor penegakan hukum yaitu penerapan peran penegakan hukum. Satjipto Rahardjo, Masalah Penegakan Hukum: (Suatu Tinjauan Sosiologi, Bandung):

Lemahnya mentalitas aparat penegak hukum mengakibatkan penegakkan hukum tidak berjalan sebagaimana mestinya. Banyak faktor yang mempengaruhi lemahnya mentalitas aparat penegak hukum diantaranya lemahnya pemahaman agama, ekonomi, proses rekruitmen yang tidak transparan dan lain sebagainya. Sehingga dapat dipertegas bahwa faktor penegak hukum memainkan peran penting dalam memfungsikan hukum.

b. Faktor Hukumnya Itu Sendiri

Ketentuan hukum kurang jelas dan tidak tersedianya penjelasan yang memadai bahkan tidak adanya penjelasan sama sekali, akan membuat adanya multi tafsir pada masingmasing pihak akan memiliki penafsiran berbeda.

Polisi Lalu lintas yang melakukan tindak pidana diadukan/dilaporkan oleh masyarakat, Polisi Lalu Lintas atau sumber lain yang dapat dipertanggungjawabkan sesuai dengan pelanggaran yang dilakukan Polantas. Adanya beberapa jenis proses peradilan dan hukuman dapat menjadi celah dalam memberikan tindakan dan sanksi bagi anggota Kepolisian yang melakukan pelanggaran atau tindak pidana.

Hukuman disiplin dapat berupa Pasal 9 Peraturan Pemerintah Nomor 2 Tahun 2003 tentang Peraturan Disiplin Anggota Kepolisian Negara Republik Indonesia:

1. teguran tertulis;

2. penundaan mengikuti pendidikan paling lama 1 (satu) tahun;

3. penundaan kenaikan gaji berkala;

4. penundaan kenaikan pangkat untuk paling lama 1 (satu) tahun;

5. mutasi yang bersifat demosi;

6. pembebasan dari jabatan;
7. penempatan dalam tempat khusus paling lama 21 (dua puluh satu) hari.

Jika hukum tertulis yang mengatur suatu bidang kehidupan tertentu dan bidang-bidang lainnya yang berkaitan berada dalam kepincangan. penegakan hukum terhadap peraturan baik disiplin, kode etik dan pidana terhadap anggota Polri saat ini dirasakan masih jauh dari harapan dan belum mampu secara maksimal memberikan dampak negatif bagi perilaku anggota Polri baik dikarenakan proses dari penegakan hukumnya maupun hasil dari penegakan hukum peraturan disiplin, kode etik, atau tindak pidana masih terjadi perbedaan persepsi tentang pelaksanaan hukuman yang diberikan dalam melakukan pelanggaran.

3.4. Faktor Masyarakat/Korban Yang Tidak Melaporkan Adanya Penganiayaan Yang Dilakukan Anggota Polisi Lalu Lintas Kepada Propam

Masyarakat menjadi korban penganiayaan dalam berkendara motor yang dilakukan oleh polisi Lalu Lintas, terkadang enggan untuk melaporkan ke Pihak propam Polrestabes Makassar. Keengganan ini dapat dijadikan salah satu penyebab pihak Propam yang merupakan penegak hukum di Kepolisian tidak memproses laporan adanya tindakan penganiayaan yang dilakukan oleh Polisi Lalu Lintas. Op Chit. Soerjono Soekanto, Teori Sosiologi tentang Pribadi dalam Masyarakat, (Jakarta: Ghalia Indonesia, 1998),

Korban penganiayaan dalam bermotor dapat melaporkan kepada Propam. Provos adalah satuan fungsi pada Kepolisian Negara Republik Indonesia yang bertugas membantu pimpinan untuk membina dan menegakkan disiplin serta memelihara tata tertib kehidupan anggota Kepolisian Negara Republik Indonesia. Korban penendangan diatas motor yang mendapatkan penganiayaan, cenderung tidak mau melaporkan adanya tindakan kekerasan kepada Kepolisian. Pengendara motor yang ditendang di atas motor sampai terjatuh dan mengakibatkan luka-luka.

Dalam pelaksanaan penyampaian pendapat di muka umum, Polri bertanggung jawab menyelenggarakan pengamanan untuk menjamin keamanan dan ketertiban umum sesuai dengan prosedur yang berlaku.

3.5. Langkah Yang Seharusnya Ditempuh Propam Polrestabes Makassar Terhadap Polantas Yang Melakukan Penganiayaan Kepada Pengendara Motor

a. Memaksimalkan Mentalitas Kinerja Propam Polrestabes Makassar Dalam Penegakan Hukum Polantas Yang Melakukan Pelanggaran

Fungsi Seksi Propam dengan yang bertugas langsung melaksanakan pengawasan dan penindakan dapat dijalankan secara maksimal terhadap Polisi Lalu Lintas yang bermasalah. Oleh karena itu apabila Tugas dan tanggungjawab Propam Polrestabes makassar ingin dapat berjalan secara maksimal dan sesuai harapan, maka harus dilaksanakan dan berlandaskan pada peraturan perundang-undangan yang telah ada yaitu:

1. Peraturan Pemerintah Republik Indonesia nomor 1 tahun 2003 tentang pemberhentian anggota Kepolisian Negara Republik Indonesia.

2. Peraturan Pemerintah Republik Indonesia nomor 2 tahun 2003 tentang peraturan disiplin anggota Kepolisian Negara Republik Indonesia.

3. Peraturan Pemerintah Republik Indonesia nomor 3 tahun 2003 tentang pelaksanaantehnis institusional peradilan 
umum bagi anggota Kepolisian Negara Republik Indonesia.

4. Keputusan Kapolri No.Pol.: KEP/42/IX/2004 tentang atasan yang berhak menjatuhkan hukuman disiplin dilingkungan Kepolisian Negara Republik Indonesia.

5. Keputusan Kapolri No.Pol.: KEP/43/IX/2004 tentang tata cara penyelesaianpelanggaran disiplin anggota Kepolisian Negara Republik Indonesia.

6. Keputusan Kapolri No.Pol.: KEP/44/IX/2004 tentang tata carasidang disilpin bagianggota Kepolisian Negara Republik Indonesia.

7. Peraturan Kapolri No.Pol.: 7 tahun 2006 tentang Kode etik profesi KepolisianNegara Republik Indonesia.

8. Peraturan Kapolri No.Pol.: 8 tahun 2006 tentang organisasi dan tata kerja komisikode etik Kepolisian Negara Republik Indonesia.

b. Memahami Produk hukum dan perundang-undangan Dalam Pelaksanaan Penegakan Hukum Yang Profesional Dan Akuntabel

Menurut Jimly Asshiddiqie "para penegak hukum dapat dilihat pertama-tama sebagai orang atau unsur manusia dengan kualitas, kualifikasi, dan kultur kerjanya masingmasing. Kedua, penegak hukum dapat pula dilihat sebagai institusi, badan atau organisasi dengan kualitas birokrasinya sendiri-sendiri"

Aparat penegak hukum memiliki fungsi yang sangat strategis dan signifikan dalam menegakan hukum. Hal ini tercermin dari para aparat penegak hukum itu merupakan salah satu unsur yang paling berpengaruh dalam penegakan hukum

1. Melakukan pelatihan teknis pelaksanaan penyidikan perkara Pelanggaran Disiplin, kegiatan rapat kerja teknis Internal propam dan kegiatan pelaksanaan supervise Internal Propam

2. Melaksanakan kegiatan pelatihan teknis pelaksanaan Penyidikan perkara pelanggaran disiplin dengan materi pelatihan:

a) Pembuatan laporan / pengaduan, penyelidikan.

b) Teknik pemeriksaan saksi dan terperiksa.

c) Penerapan pasal, pembuatan resume dan pemberkasan perkara pelanggarandisiplin.

d) Pembuatan persangkaan dan tuntutan perkara pelanggaran disiplin.

e) KUH Pidana dan KUHAP.

f) Juklak dan Juknis penyidikan tindak pidana.

g) Peraturan Pemerintah Rl NO.1 Tahun 2003 tentang Pemberhentian AnggotaPolri, Peraturan Pemerintah RI NO.2 Tahun 2003 tentang Peraturan Disiplin Anggota Polda, Peraturan pemerintah RI NO.3. Tahun 2003 tentang pelaksanaan teknis Institusional peradilan umum bagi anggota Polda dan

h) Peraturan Kapolri No.7 dan No.14 Tahun 2011 tentang Kode Etik Polri.

c. Inisiatif Propam Polri Dalam Melakukan Penyidikan Dan Menerima Laporan Pengaduan Dari Korban Penganiayaan Lalu Lintas

Berawal dari adanya laporan dan pengaduan yang masuk tentang terjadinya pelanggaran disiplin,. Propam melakukan Pemanggilan untuk pemeriksaan saksi anggota Polri. Dalam kasus pelanggaran disiplin yang dilaporkan masyarakat dan berdampak pada citra Polri yang memerlukan percepatan pemeriksaan dan laporan kepada pimpinan atas kasus yang terjadi dengan Penerapan pasal atas pelanggaran disiplin secara tepat.

Propam Polri yang memiliki banyak referensi hukum dan perundang-undangan, baik yang berlaku umum maupun yang berlaku khusus di internal Polri. Sehingga dalam perkembangan proses penyidikan perkara pelanggaran disiplin, anggota Polri dipublikasikan secara luas kepada masyarakat terutama kepada pihak pelapor yang menjadi korban, disampaikan penjelasan secara tertulis oleh pihak penyidik Propam Polri.

Dengan kondisi penegakan hukum yang memiliki insiatif disiplin anggota Polri yang sesuai harapan niscaya akan menjadikan tegaknya disiplin anggota signifikan seiring dengan paradigma baru Polri sebagai polisi yang profesional, obyektif, transparan, dan akuntabel.

\subsection{Sanksi Bagi Oknum Polisi Lalu Lintas Yang Melakukan Penganiayaan Kepada Pengendara Motor}

Pada dasarnya, dalam melaksanakan tugas dan wewenangnya, pejabat Kepolisian Negara Republik Indonesia senantiasa bertindak berdasarkan norma hukum dan mengindahkan norma agama, kesopanan, kesusilaan, serta menjunjung tinggi hak asasi manusia. Hal ini sebagaimana diatur dalam Pasal 19 Undang-Undang No. 2 Tahun 2002 tentang Kepolisian Negara Republik Indonesia.

Jika polisi harus melakukan tindakan kekerasan, maka tindakan tersebut harus mempertimbangkan hal-hal sebagaimana disebut dalam Pasal 45 Perkapolri 8/2009, yaitu:

a. Tindakan dan cara-cara tanpa kekerasan harus diusahakan terlebih dahulu;

b. Tindakan keras hanya diterapkan bila sangat diperlukan;

c. Tindakan keras hanya diterapkan untuk tujuan penegakan hukum yang sah;

d. Tidak ada pengecualian atau alasan apapun yang dibolehkan untuk menggunakan kekerasan yang tidak berdasarkan hukum;

e. Penggunaan kekuatan dan penerapan tindakan keras harus dilaksanakan secara proporsional dengan tujuannya dan sesuai dengan hukum;

f. Penggunaan kekuatan, senjata atau alat dalam penerapan tindakan keras harus berimbang dengan ancaman yang dihadapi;

g. Harus ada pembatasan dalam penggunaan senjata/alat atau dalam penerapan tindakan keras; dan

h. Kerusakan dan luka-luka akibat penggunaan kekuatan/tindakan keras harus seminimal mungkin.

3.7. Kendala yang dihadapi Kepolisian dalam Penanggulangan Pelanggaran Lalu Lintas oleh Anak sebagai Pengendara Sepeda Motor

Penanggulangan diartikan sebagai usaha untuk mencegah dan mengurangi pelanggaran lalu lintas yang dilakukan oleh anak.Usaha peningkatan kegiatan lebih diarahkan kepada usaha pre-emtif, preventif dan represif. Sesuai dengan fungsi kepolisian yang dimuat didalam Pasal 13 Undang-Undang Nomor 2 Tahun 2002 Tentang Kepolisian Republik Indonesia yaitu memelihara keamanan dan ketertiban, menegakkan hukum serta memberikan perlindungan, pengayoman dan pelayanan kepada masyarakat. Dalam menanggulangi pelanggaran lalu lintas yang dilakukan oleh anak, terdapat beberapa kendala yang dihadapi Kepolisian Resor Kota makassar dalam menanggulangi pengendara sepeda motor oleh anak seperti: 


\section{Kurangnya Personil}

Salah satu faktor yang menghambat kinerja Polisi Lalu Lintas dalam menjalankan tugasnya yaitu kurangnya personil polisi satuan lalu lintas, adanya oknum aparat penegak hukum yang mau menerima suap dan kurang patuh dengan aturan yang berlaku dalam Undang-Undang Nomor 22 Tahun 2009 Tentang Lalu Lintas dan Angkutan Jalan dan faktor sarana dan fasilitas.

2. Kurangnya Kesadaran Hukum Pada Anak

Kurangnya kesadaran hukum pada anak dalam mematuhi aturan-aturan yang ditentukan dalam berkendara di jalan raya, dimana seorang anak belum boleh mengendarai kendaraan bermotor di jalan raya, selain sangat berbahaya bagi dirinya juga berbahaya bagi pengendara lain maupun pengguna jalan yang berada di jalan raya, juga karena anak tersebut belum cukup umur untuk memiliki SIM.

3.8. Dampak Penerapan Prinsip Restorative justice Dalam Penyelesaian Perkara Tindak Pidana Lalu Lintas

a. Dasar Pelaksanaan Restorative Justice dalam Penyelesaian Perkara Tindak Pidana Lalu Lintas

Penyelesaian perkara tindak pidana lalu lintas adalah suatu proses yang ditempuh untuk menyelesaikan masalah yang ditimbulkan melalui proses peradilan maupun diluar proses peradilan. Setiap perkara pada setiap kecelakaan lalu lintas harus diselesaikan sesuai dengan ketentuan peraturan perundang-undangan. Hal ini sesuai dengan penjelasan Pasal 230 Undang-Undang Nomor 22 Tahun 2009 Tentang Lalu Lintas dan Angkutan Jalan. Dan setiap pengemudi yang karena kelalaiannya mengakibatkan kecelakaan lalu lintas wajib bertanggung jawab atas kerugian yang diderita korban dan hal ini sesuai dengan ketentuan Pasal 234 UndangUndang Nomor 22 Tahun 2009 Tentang Lalu Lintas dan Angkutan Jalan. Kecelakaan lalu lintas yang mengakibatkan korban luka berat maupun meninggal dunia juga dapat dijatuhkan sanksi berdasarkan Pasal 359 dan pasal 360 KUHP.

Perlu diketahui Alternatif Dispute Resolution (ADR) merupakan pola penyelesaian masalah sosial melalui jalur alternatif selain proses hukum atau non litigasi antara Namun demikian, Berdasarkan Peraturan Kepala Kepolisian Negara

Republik Indonesia Nomor 7 Tahun 2008 Tentang Pedoman Dasar Strategi Dan Implementasi Pemolisian Masyarakat Dalam Penyelenggaraan Tugas Polri yaitu pada pasal 14 poin f bahwa "penerapan Konsep Alternative Dispute Resolution (pola penyelesaian masalah sosial melalui jalur alternatif yang lebih efektif berupa upaya menetralisir masalah selain melalui proses hukum atau non litigasi) misalnya melalui upaya perdamaian" yang kemudian dipertegas dalam Surat Kapolri No Pol: B/3022/XII/2009/SDEOPS tanggal 14 Desember 2009, maka Pihak Kepolisian memiliki kewenangan untuk mengambil pola penyelesaian permasalahan hukum dengan melalui Alternatif Dispute Resolution (ADR).

b. Penyelesaian Perkara Tindak Pidana Lalu Lintas Di Polrestabes Makassar

Tata cara penyelesaian perkara (crime clearance) tindak pidana oleh kepolisian dalam pelaksanaannya perlu mekanisme secara transparansi dan akuntabel, dengan syarat:

1. Diutamakan melindungi kepentingan korban, agar tidak dirugikan;

2. Libatkan sistem sosial masyarakat atau forum kemitraan polisi dan masyarakat (FKPM);
3. Adanya partisipasi dan pengawasan yang ketat, agar pelaksanaan penyelesaian perkara (crime clearance) tindak pidana tidak disalah gunakan.

Wawancara dengan Aiptu Sumadi Unit Laka Satlantas Polrestabes Makassar.

Adapun tatacara pelaksanaan penyelesaian kasus dengan restorative justice adalah sebagai berikut:

1. Undangan/panggilan kepada kedua belah pihak untuk klarifikasi

2. Interogasi mengenai kronologis kasus

3. Pembuatan Berita Acara Pemeriksaan

4. Mediasi dilaksanakan oleh penyidik yang menangani kasus sebagaifasilitator sekaligus mediator. Dalam mediasi korban dan pelaku boleh didampingi atau diwakili oleh keluarga, kerabat maupun tokoh masyarakat seperti RT/RW.

5. Mediasi juga bisa dilakukan tanpa melibatkan polisi yaitu pelaku dan korban ataupun keluarga masingmasing bertemu secara pribadi dan membuat kesepakatan dengan bentuk surat pernyataan damai. Tabel 1: Data Laka Lantas dan Penyelesaian Perkara Tahun 2019 Di Kota Makassar

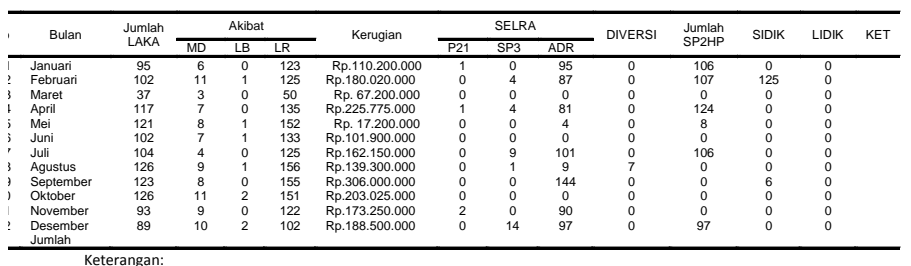

MD: Meninggal Dunia
- LB : Luka Berat

LR : Luka Berat

Berdasarkan Tabel 1 data laka lantas dan penyelesaian perkara Tahun 2019 yang dikeluarkan oleh Unit Satuan Lalu Lintas Polrestabes Makassar, maka dapat ditarik kesimpulan bahwa Restorative Justice diterapkan dalam penyelesaian perkara tindak pidana lalu lintas di Polrestabes Makassar

Secara yuridis sanksi yang dijatuhkan oleh propam Polri tidak menjadi permasalahan selama tidak melebihi batas minimum dan maksimum sanksi pidana yang diancamkan dalam pasal yang bersangkutan, melainkan yang menjadi persoalan adalah apa yang mendasari atau apa alasan dalam menjatuhkan hukuman berupa sanksi administratif sehingga hukuman yang dijatuhkan secara objektif dapat diterima dan memenuhi rasa keadilan bagi masyarakat luas pada umumnya dan bagi saksi korban dan juga pelaku pada khususnya.

Surat perintah yang diajukan oleh kepala kepolisian resort makassar merupakan salah satu alat yang penting yang digunakan oleh propam polri dalam menelaah faktor-faktor dan pertimbangan-pertimbangan dalam menjatuhkan suatu hukuman.

Berdasarkan fungsinya, Propam Polri menjadikan surat perintah sebagai pedoman didalam melakukan pemeriksaan dipersidangan dan tentunya dijadikan sebagai acuan dasar dalam menjatuhkan putusan.

Propam Polri sendiri tidak boleh memidanakan orang yang bersalah atas perbuatannya bilamana perbuatan tersebut tidak dimasukkan kedalam surat dakwaan meskipun yang terbukti bahwa pelaku melakukan tindak pidana berdasarkan fakta yang terungkap dipersidangan.

Berdasarkan segala pertimbangan yang dijadikan Propam Polri dalam menjatuhkan putusan terhadap Pelaku, menurut penulis sudah tepat. Hal tersebut dapat kita lihat 
bahwa berdasarkan surat dakwaan primair subsidair yang diajukan oleh korban yang oleh Propam Polri sangat penting dalam menentukan dan menjatuhkan sanksi kepada pelaku dengan melihat secara keseluruhan serangkaian perbuatan pelaku yang kemudian harus diuji dan dibuktikan kesemua unsur-unsur dari tindak pidana.

Oleh karena surat perintah yang digunakan Propam Polri bersifat primair subsidair, yang pada dakwaan primairnya, unsur-unsur perbuatan pidana yang dilakukan oleh pelaku telah terpenuhi berdasarkan alat bukti yang ada dan pemeriksaan yang telah dilakukan sepanjang persidangan, maka dakwaan subsidair tidak perlu lagi diuji dan dibuktikan kesemua unsur-unsurnya.

Dengan memperhatikan pula hal-hal apa saja yang menjadi bahan pertimbangan Propam Polri dalam menjatuhkan pidana terhadap pelaku sudah sangat bersesuaian dengan tindak pidana yang telah dilakukan olehnya. Dengan melihat secara keselurahan dari rangkaian tindakan pelaku, alat-alat bukti dipersidangan, kasaksian para saksi, keterangan pelaku, hingga pemeriksaan menjatuhkan sansi sesuai putusan yang berlaku di lingkungan kepolisian yang dianggap sudah sangat sepadan dengan tindakan yang dilakukan oleh pelaku.

Dari uraian - uraian yang dikemukakan diatas maka dapat disimpulkan bahwa perbuatan pelaku telah dapat dibuktikan secara sah dan memenuhi semua unsur - unsur rumusan tindak pidana penganiayaan yaitu Pasal 351 ayat (1) KUHP. Sebelum menjatuhkan pidana, terlebih dahulu Sie Propam Polrestabes Makassar akan mempertimbangkan halhal yang dapat dijadikan dasar sebagai alasan yang dapat meringankan atau yang dapat memberatkan pidana pelaku, dimana berdasarkan wawancara dengan Propam Polrestabes makassar yang bertugas mengadili perkara ini yaitu Awaluddin beliau mengatakan bahwa :

"Dari hasil pemeriksaan di persidangan ternyata pada diri pelaku tidak ada ditemukan alasan - alasan yang dapat meringankan atau menghilangkan pertanggungjawaban pidana baik alasan pembenar maupun alasan pemaaf, sehingga pelaku dinilai mampu bertanggung jawab atas kesalahannya, oleh karena itu kepadanya haruslah dijatuhi pidana yang setimpal dengan kesalahannya tersebut".

Jadi pertanggungjawaban seseorang yang melakukan tindak pidana penganiayaan dalam kasus ini tidak adanya alasan - alasan yang ditemukan dalam persidangan baik melalui bukti - bukti yang dapat menjadi alasan penghapusan pidana sehingga pelaku dianggap sehat jasmani dan rohaninya melakukan tindak pidana tersebut. Alasan tersebutlah Sie Propam Polri menjatuhkan putusan pemberian sanksi.

Adapun hal-hal yang memberatkan dan meringankan pelaku adalah sebagai berikut:

Hal-hal yang memberatkan:

- Perbuatan Pelaku meresahkan masyarakat

- Pelaku adalah Anggota Polisi Lalu Lintas yang seharusnya memberikan contoh yang baik bagi masyarakat

Hal-hal yang meringankan:

- Pelaku bersifat sopan selama pemeriksaan di Propam Polrestabes Makassar

- Pelaku menyesali perbuatannya dan berjanji tidak akan mengulanginya lagi;

- Pelaku telah meminta maaf kepada korban

- Pelaku belum pernah dihukum

- Pelaku mempunyai tanggungan keluarga
Berdasarkan uraian diatas serta hasil wawancara dengan beberapa narasumber yang berkompeten dalam perkara ini maka penulis berkesimpulan bahwa pertimbangan hukum Sie Propam dalam menjatuhkan putusan telah sesuai dengan ketentuan yang berlaku berdasar pada semua fakta-fakta serta bukti-bukti yang terungkap dalam persidangan di Sie Propam.

\section{KESIMPULAN DAN SARAN}

Hasil penelitian dan pembahasan dapat disimpulkan bahwa bahan Pertanggungjawaban pidana terhadap polisi Lalu Lintas yang melakukan penganiayaan terhadap pengendara motor belum terlaksana sebagaimana mestinya terbukti tidak adanya proses peradilan umum dan pemberian sanksi pidana, akan tetapi Propam Polri sudah melakukan tindakan sidang pelanggaran disiplin / Kode Etik kepada anggota polisi yang melakukan pelanggaran yaitu sanksi administratif berupa mutasi tugas sebagai Penjagaan Satuan Sabara pada Kantor Kepolisian Daerah Sulawesi Selatan. Langkah yang seharusnya ditempuh propam polri terhadap polantas yang melakukan penganiayaan Lalu Lintas dengan cara : Memaksimalkan Mentalis kinerja propam polri dalam penegakan hukum disiplin Anggota polri, memahami produk Hukum dan perundang - undangan dalam pelaksanaan penegakan hukum yang profesional dan Akuntabel, dan Inisatif propam Polri dalam melakukan penyidikan dan menerima Laporan Pengaduan dari Korban Penganiayaan. Dampak penganiayaan yang dilakukan oleh polisi Lalu Lintas terhadap anggota masyarakat adalah menimbulkan lukaluka pada bagian mata sebelah kiri, luka pada bagian belakang telinga, dan luka pada tangan sebelah kiri. Akan tetapi, luka ini termasuk luka ringan karena tidak menyebabkan korban cacat permanen, tidak bisa melakukan aktifitas seperti biasa, namun dengan adanya peristiwa ini membuat citra institusi kepolisian sebagai lembaga pengayom berkonotasi negatif ,termasuk salah satunya kurangnya respon positif dan simpati masyarakat terhadap polisi Lalu Lintas

\section{DAFTAR PUSTAKA}

Rachmadi Usman, 2001, Aspek-Aspek Hukum Perbankan Di Indonesia, Gramedia, Jakarta.

Citra, Nur Azizah, 2011. Sripsi. Tinjauan Kriminologis Tindak Pidana Pencabulan yang Oilakukan Oleh Oknum Anggota Kepolisian di Wilayah Hukum Polda Sulselbar. Makassar: Universitas Hasanuddin.

Hamzah Andi, 1993. Sisfem Pidana dan Pemidanaan di Indonesia, Jakarta: Pradnya Paramita.

Lamintang P.A.F, 1997. Dasar-Dasar Hukum Pidana Indonesia, Bandung: Citra Aditya.

Marpaung Leden. 2005. Asas-Teori-Praktek Hukum Pidana, Jakarta: Sinar Grafika.

Nawawi Arif Barda, 2003. Kapita Selekta Hukum Pidana, Bandung: Citra Aditya Bakti.

Prodjodikoro Wirjono, 2003. Tindak-Tindak Pidana Tertentu Di Indonesia, Bandung: Rafika Aditama.

Prodjodikoro Wirjono, 1981. Asas-Asas Hukum Pidana di Indonesia, Bandung: Eresco. 
Rahardjo Satjipto.1993. Masalah Penegakan Hukum, Suatu Tinjauan Sosiologis, Bandung: Sinar Baru.

Renggong Ruslan, 2016, Hukum Pidana Khusus Memahami Delik - Delik di Luar KUHAP, Jakarta:Prenadamedia Group.

Rusli Muhammad, 2005. Potret Lembaga Peradilan Indonesia, Yogyakarta: Fakultas Hukum Universitan Islam Indonesia.

Saleh, Roeslan, 1983. Stelse! Pidana Indonesia, Jakarta: Aksara Baru.

Schaffmeister D, Keijzer N, Sutorius PH, 1991.Hukum Pidana, Bandung: Citra Aditya Bakti.

Soekanto Soerjono. 2005. Faktor-faktor yang Mempengaruhi Penegakan Hukum, Jakarta: Raja Grafindo Persada.

Soesilo R. 1995. Kitab Undang-Undang Hukum Pidana (KUHP) Serta Komentar-komentarnya Lengkap Pasal Oemi Pasal,Bogor: Politeia.

Tongat, 2009, Dasar-Dasar Hukum Pidana Dalam Perspektif Pembaharuan, Malang, UMM Press.

Triyanto Lukmantoro. Kekerasan Negara dan Perlawanan Mahasiswa Di Tengah Krisis. Jurusan Ilmu Komunikasi FISIP Universitas Diponegoro Semarang. 1997.

Wiclaningsih, Yuyun, IIyas Amir, 2010. Hukum Korporasi Rumah Sakit., Yogyakarta: Rangkang Education

Zainal Abidin Farid, A. dan Andi Hamzah, 2006, Bentuk Bentuk Khusus Perwujudan Delik (Percobaan Penyertaan, Dan Gabungan Delik) Dan Hukum Penitensier, Jakarta

Kitab Undang-Undang Hukum Pidana (KUHP)

Kitab Undang-Undang Hukum Acara Pidana (KUHAP)

Undang-Undang RI No. 8 Tahun 1981 tentang Kitab Undang-Undang Hukum Pidana (KUHP).

Undang-Undang RI No. 2 Tahun 2002 tentang Kepolisian Negara Republik Indonesia.

Undang-Undang No. 22 tahun 2009 tentang Lalu Lintas dan Angkutan Jalan. 